\title{
Comparing the thermo-physical characteristics of lard and selected plant fats
}

\author{
By N.A.M. Yanty ${ }^{a}$, J.M.N. Marikkar ${ }^{a, *}$ and M.S. Miskandar ${ }^{b}$ \\ ${ }^{a}$ Halal Products Research Institute, Putra Inforport, Universiti Putra Malaysia, \\ 43400 UPM Serdang, Selangor D.E., Malaysia \\ ${ }^{\mathrm{b}}$ Malaysian Palm Oil Board, No. 6 Persiaran Institusi, Bandar Baru Bangi, \\ 43000 Kajang, Selangor D.E., Malaysia \\ *Corresponding author: nazrim_marikkar@ putra.upm.edu.my
}

\section{RESUMEN}

Comparación de las características termo-físicas de la manteca y seleccionadas grasas de plantas.

La comparación de las propiedades térmica y mecánicas de la manteca de cerdo y la de determinadas grasas de plantas, podría ayudar a formular sustitutos alternativos de las grasas para aplicaciones alimentarias. En este estudio, basado en materias grasas vegetales como, aguacate (Persea americana), manteca de cacao (Theobroma cacao L.), palma aceitera (Elaeis guinensis) y grasa de mee (Madhuca longifolia) se comparan con la manteca de cerdo con respecto a parámetros físico-químicos, composiciones en ácidos grasos y triglicéridos (TAG), y comportamientos de los parámetros de fusión y de solidificación. Aunque las grasas de plantas son completamente diferentes a la manteca de cerdo, con respecto a la composición de ácidos grasos y de TAG, comparten algunas características comunes térmicas con la manteca de cerdo. A partir del análisis térmico, la manteca de cerdo y las grasas vegetales, excepto la manteca de cacao, muestran tener transiciones térmicas en ambas, baja $\left(<0^{\circ} \mathrm{C}\right)$ y alta $\left(>0^{\circ} \mathrm{C}\right)$, regiones de fusión de sus curvas de enfriamiento y fusión. De acuerdo con los datos de RMN de pulso, la grasa de mee y la manteca de cerdo muestran perfiles de solidificación muy similares en el intervalo de temperatura de 0 a $25^{\circ} \mathrm{C}$, mientras que el aceite de palma y la manteca de cerdo tienen perfiles similares de solidificación en el intervalo de temperaturas entre 25 a $40^{\circ} \mathrm{C}$. Por lo tanto, la comparación de las propiedades termo-físicas entre las grasas vegetales y la manteca pueden ser de utilidad para formular mezclas grasas simulando las propiedades térmicas de la manteca de cerdo.

PALABRAS CLAVE: Manteca de Aguacate - Manteca de cacao, Manteca de cerdo - Grasas de plantas - Comportamiento de solidificación - Análisis térmico.

\section{SUMMARY}

Comparing the thermo-physical characteristics of lard and selected plant fats.

A comparison of the thermo-physical properties of lard and plant fats may help to formulate alternative fat substitutes for halal food applications. In this study, plant-based fats, namely avocado butter (Persea americana), cocoa butter (Theobroma cacao L.), palm oil (Elaeis guinensis) and mee fat (Madhuca longifolia) are compared to lard with respect to the basic physico-chemical parameters, fatty acid and triacylglycerol (TAG) compositions, and melting and solidification behaviors. Although plant fats are completely different from lard with respect to fatty acid and TAG compositions, they share some common thermal features with lard. Based on thermal analysis, lard and plant fats, except cocoa butter, are found to have thermal transitions in both low $\left(<0^{\circ} \mathrm{C}\right)$ and high $\left(>0^{\circ} \mathrm{C}\right)$ melting regions of their cooling and melting curves. According to pulse NMR data, mee fat and lard are found to display closely similar solidification profiles in the temperature range of $0-25^{\circ} \mathrm{C}$, while palm oil and lard are found to have similar solidification profiles in the temperature range between $25-40^{\circ} \mathrm{C}$. Hence, the thermo-physical property comparison between plant fats and lard may be useful to formulate a fat blend which simulates the thermal properties of lard.

KEY-WORDS: Avocado butter - Cocoa butter-Lard-Plant fats - Solidification behavior - Thermal analysis.

\section{INTRODUCTION}

Animal body fats such as lard, beef tallow, mutton tallow and chicken fat have long been used as fat ingredients in food applications. The issue of mixing lard with food is one of the unresolved outstanding issues, which has caused uneasiness amongst consumers belonging to certain religious groups. For instance, lard has been used as an ingredient in certain types of biscuits, dripping sandwiches, snacks, rice and moon cakes (Wikipedia, 2011). Owing to the growing public concern about the halal status of food in many parts of the world, producing safe and high quality halal food is a prerequisite to ensure consumer health and successful domestic and international trade (Riaz and Chaudry, 2004). However, only few research studies have been reported in relation to the development of alternative plant-based ingredients for halal applications. Although Ospina-E et al., (2011) investigated an alternative for pork backfat in sausage formulation using several combinations of chemically modified vegetable oils, their study did not include plant-based fats such as avocado butter (Persea americana), cocoa butter, mee fat (Madhuca longifolia), etc. Detailed investigations on the solidification and melting behavior of these fats are particularly important for the formulation of a fat blend which simulates the properties of lard to be used as an all purpose shortening in cookies, etc. Hence, in this 
study, differential scanning calorimetry and pulse NMR techniques have been employed to compare the thermo-physical properties of four plant-based fats (palm oil, avocado butter, cocoa butter and mee fat) and lard.

\section{MATERIALS AND METHODS}

\subsection{Materials}

Lard was extracted using three batches of adipose tissues of swine collected from local slaughter houses according to the method reported previously by Marikkar et al. (2001). Dried fruit seeds of Madhuca longifolia were collected from three different locations in the North Central Province of Sri Lanka. Avocado fruits were collected from two locations in West Malaysia. A sample of palm oil was obtained as a generous gift from the Malaysian Palm Oil Board (MPOB). Cocoa butter was purchased from the Malaysian Cocoa Board. All chemicals used in this experiment were of analytical or HPLC grade.

\subsection{Oil extraction}

Oil extraction from finely ground samples of dried avocado fruits and mee seeds was carried out using the soxhlet extraction method with petroleum ether $\left(40-60^{\circ} \mathrm{C}\right)(\mathrm{AOAC}, 2007)$. The extracted oils were kept in an oven at $60^{\circ} \mathrm{C}$ for $1 \mathrm{~h}$ to expel the solvent before storing at $-20^{\circ} \mathrm{C}$. Before analysis, the oil samples were removed from frozen storage, and left to stand at room temperature for $1 \mathrm{~h}$ and then warmed at $60^{\circ} \mathrm{C}$ until they became completely molten.

\subsection{Determination of slip melting point (SMP) and iodine value (IV)}

The SMP and IV of the fat samples were determined according to the AOCS method Cc.3.25, and the AOCS method $\mathrm{Cd}$ Id-92, respectively (AOCS, 1999).

\subsection{Determination of fatty acid composition}

Fatty acid methyl esters (FAME) were prepared by dissolving a $50 \mathrm{mg}$ portion of oil in $0.8 \mathrm{~mL}$ of hexane and adding a $0.2 \mathrm{~mL}$ portion of a $1 \mathrm{M}$ solution of sodium methoxide (PORIM, 1995), followed by analysis on a gas chromatograph (Agillent Technologies, Singapore) fitted with an FID detector. The polar capillary column RTX-5 (0.32 $\mathrm{mm}$ internal diameter, $30 \mathrm{~m}$ length and 0.25 $\mu \mathrm{m}$ film thickness; Restex Corp., Bellefonte, PA) was used. The oven temperature was programmed as follows: initial temperature of $50^{\circ} \mathrm{C}$ (for $1 \mathrm{~min}$ ), programmed to increase to $200^{\circ} \mathrm{C}$ at $8^{\circ} \mathrm{C}$ per $\mathrm{min}^{-1}$. Both injector and detector temperatures were maintained at $200^{\circ} \mathrm{C}$ throughout the analysis. The carrier gas (helium) flow rate was $1.0 \mathrm{~mL} \mathrm{~min}{ }^{-1}$ and the split ratio was 58:1. The identification of the peaks of the samples was made with reference to a chromatographic profile containing FAME standards (Supelco, Bellefonte, PA). The percentage of fatty acid was calculated as the ratio of the partial area to the total peak area (Marikkar et al., 2003).

\subsection{Determination of TAG composition}

The TAG composition was determined using a Waters Model 510 liquid chromatography equipped with a differential refractometer Model 410 as the detector (Waters Associates, Milford, MA). The analysis of TAG was performed on a Merck Lichrosphere RP-18 column $(5 \mu \mathrm{m})(12.5 \mathrm{~cm} \times 4$ $\mathrm{mm}$ i.d.; Merck, Darmstadt, Germany). The mobile phase was a mixture of acetone:acetonitrile (63.5:36.5) and the flow rate was $1.5 \mathrm{~mL} \mathrm{~min}^{-1}$. The oven temperature was maintained at $30^{\circ} \mathrm{C}$. The injector volume was $10 \mu \mathrm{L}$ of $5 \%(\mathrm{w} / \mathrm{w})$ oil in chloroform. Each sample was analyzed as three replicates, and the data were reported as area percentage (Marikkar et al., 2003). The identification of the peaks of the samples was made using a set of TAG standards purchased from Sigma-Aldrich (Deisehofen, Germany) as well as the TAG profiles of lard (Yanty et al., 2011a), palm oil (Marikkar et al., 2005), cocoa butter (Segall et al., 2005), mee fat (Marikkar et al., 2010) and avocado butter (Yanty et al., 2012; Yanty et al., 2011b) reported previously.

\subsection{Thermal analysis by differential scanning calorimetry (DSC)}

Thermal analysis was carried out on a Mettler Toledo differential scanning calorimeter (DSC 823 Model) equipped with a thermal analysis data station (STARe software, Version 9.0x, Schwerzenbach, Switzerland). Nitrogen (99.99\% purity) was used as the purge gas at a rate of $\sim 20$ $\mathrm{mL} \mathrm{min}^{-1}$. Approximately 4-8 $\mathrm{mg}$ of molten sample were placed in a standard DSC aluminum pan and then hermetically sealed. An empty, hermeticallysealed DSC aluminum pan was used as the reference. The oil/fat samples were subjected to the following temperature program: The sample was held at $70^{\circ} \mathrm{C}$ isotherm for $1 \mathrm{~min}$ to destroy the thermal history of the samples, cooled at $5^{\circ} \mathrm{C} / \mathrm{min}$ to $-70^{\circ} \mathrm{C}$ and held for $1 \mathrm{~min}$. The sample was then heated from $-70^{\circ} \mathrm{C}$ to $70^{\circ} \mathrm{C}$ at the same rate (Marikkar et al., 2003).

\subsection{Determination of solid fat content}

The solid fat content (SFC) measurement was carried out using a Bruker Minispec (Model Mq 20) pulse Nuclear Magnetic Resonance (pNMR) spectrometer (Karlsruhe, Germany), according to AOCS (1999). The sample in the NMR tube was 
melted at $90^{\circ} \mathrm{C}$ for $15 \mathrm{~min}$, followed by chilling at $0^{\circ} \mathrm{C}$ for $60 \mathrm{~min}$, and then held at each measuring temperature for $30 \mathrm{~min}$ prior to measurement. Melting, chilling and holding of the samples were carried out in pre-equilibrated thermostatted glycol containing baths, accurate to $0.1^{\circ} \mathrm{C}$. SFC measurements were taken at $5^{\circ} \mathrm{C}$ intervals over the range of $0-60^{\circ} \mathrm{C}$.

\subsection{Statistical analysis}

In all analyses, three replicates were used and the results were expressed as mean value \pm standard deviation. Data were statistically analyzed by one-way analysis of variance (ANOVA), using Tukey's Test of MINITAB (version 15) statistical package at 0.05 probability level.

\section{RESULTS AND DISCUSSION}

\subsection{The slip melting point and iodine value}

The SMP and IV of plant-based fats namely avocado butter, cocoa butter, palm oil and mee fat are compared with those of lard as shown in Table 1. The SMP of lard is $27.50^{\circ} \mathrm{C}$, which was comparable to our previous findings (Yanty et al., 2011a). All plant-based lipids are found to possess higher $\left(>27.50^{\circ} \mathrm{C}\right) \mathrm{SMP}$ than lard. Among them, only avocado butter $\left(30.0^{\circ} \mathrm{C}\right)$ is found to possess an SMP value much closer to that of lard. According to Table 1, the IV of lard was 73.76, while those of avocado butter, cocoa butter, palm oil and mee fat are 84.30, 34.00, 54.00, and 61.10, respectively. Hence, none of the plant-based fats was found to have an IV closely similar to that of lard.

\subsection{Fatty acid composition}

The fatty acid distribution of the plant-based fats and lard are compared in Table 1. The major fatty acid of lard was oleic acid (38.24\%), followed by palmitic $(22.68 \%)$ and linoleic $(20.39 \%)$ acids. According to most of the previous studies, lard is generally found to have more unsaturated fatty acids (USFA) than saturated fatty acids (SFA) (Rashood et al., 1996; Nurjuliana et al., 2010; Yanty et al., 2011a). Similar to lard, plant-based fats namely, palm oil, avocado butter and mee fat are also found to have more USFA than SFA. While the ratio of SFA/USFA of lard is 0.61 , those of palm oil, mee fat and avocado butter are 0.95, 0.78 and 0.46 , respectively. In the case of cocoa butter, it is found to have more SFA (64.25\%) than USFA $(35.75 \%)$ due to the presence of higher proportions of stearic and palmitic acids. According to Table 1, the stearic acid content of lard $(12.70 \%)$ is significantly higher $(p<0.05)$ than those of palm oil and avocado butter but significantly lower $(p<0.05)$ than those of mee fat and cocoa butter. If a fat blend simulating the fatty acid composition of lard is desired, it could be possible through blending of either avocado butter or palm oil with mee fat or cocoa butter in an appropriate ratio.

\subsection{TAG composition}

As shown in Table 2, the TAG composition of plant-based fats and lard are compared. The predominant TAGs of lard were POO $(20.67 \%)$, followed by POL (20.0\%) and StPO (12.52\%). The TAG distribution pattern of lard observed in this study is found to be comparable to the findings reported previously (Rashood et al., 1996). According to Table 2, lard is found to contain $51.34 \%$ of UUS and $26.60 \%$ of USS as the predominant TAG molecular groups. Similar to lard, avocado butter is also found to have POO (22.76\%) and POL (19.29\%) as major TAGs, but a very small amount of StPO $(0.57 \%)$. The TAG molecular classification shows that avocado butter is found to possess $46.78 \%$ of UUS, $17.03 \%$ of USS, but $26.37 \%$ of UUU. The Presence of OOO, OOL, OLL, and LLLn in higher amounts would make avocado butter have a higher proportion of UUU in comparison to lard. Although mee fat is found to possess $\mathrm{POO}$ as the predominant TAG, its second most abundant TAG molecular species was StOO. Similar to lard, mee fat is found to have UUS

Table 1

Basic physico-chemical characteristics and fatty acid composition (\%) of plant-based fats and lard

\begin{tabular}{|c|c|c|c|c|c|c|c|c|c|c|c|c|}
\hline \multirow{2}{*}{ Sample } & \multirow{2}{*}{ lodine value } & \multirow{2}{*}{$\begin{array}{l}\text { Slip melting } \\
\text { point } /{ }^{\circ} \mathrm{C}\end{array}$} & \multicolumn{10}{|c|}{ Fatty acid $/ \%$} \\
\hline & & & $\mathrm{C} 12: 0$ & C14:0 & $\mathrm{C} 16: 0$ & C16:1 & C18:0 & $\mathrm{C} 18: 1$ & C18:2 & C18:3 & $\mathrm{C} 20: 0$ & Others \\
\hline $\begin{array}{l}\text { Avocado } \\
\text { butter }^{1,2}\end{array}$ & $84.30 \pm 0.14^{\mathrm{a}}$ & $30.00 \pm 0.71^{\circ}$ & - & - & $30.37 \pm 0.06^{b}$ & $5.22 \pm 0.02^{\mathrm{a}}$ & $1.30 \pm 0.01^{e}$ & $43.65 \pm 0.04^{b}$ & $17.45 \pm 0.04^{b}$ & $2.03 \pm 0.01^{a}$ & - & - \\
\hline Cocoa butter & $34.00 \pm 1.41^{d}$ & $35.66 \pm 0.06^{b}$ & - & - & $25.34 \pm 0.04^{c}$ & - & $37.84 \pm 0.14^{\mathrm{a}}$ & $32.83 \pm 0.26^{e}$ & $2.92 \pm 0.06^{e}$ & - & $1.07 \pm 0.01^{\mathrm{a}}$ & - \\
\hline Palm oil & $54.00 \pm 0.00^{\mathrm{a}}$ & $30.50 \pm 0.71^{e}$ & $0.33 \pm 0.01^{\mathrm{a}}$ & $1.10 \pm 0.00^{b}$ & $43.99 \pm 0.20^{\mathrm{a}}$ & $0.18 \pm 0.01^{b}$ & $4.36 \pm 0.06^{d}$ & $39.24 \pm 0.20^{c}$ & $10.25 \pm 0.06^{c}$ & $0.19 \pm 0.01^{c}$ & $0.36 \pm 0.01^{c}$ & - \\
\hline Mee fat & $61.10 \pm 0.14^{\circ}$ & $35.25 \pm 0.35^{b}$ & - & - & $22.38 \pm 0.79^{d}$ & - & $21.53 \pm 0.67^{b}$ & $47.58 \pm 0.08^{\mathrm{a}}$ & $8.51 \pm 0.04^{d}$ & - & - & - \\
\hline Lard $^{3}$ & $73.76 \pm 0.34^{b}$ & $27.50 \pm 0.71^{d}$ & $0.09 \pm 0.01^{b}$ & $1.24 \pm 0.01^{\mathrm{a}}$ & $22.68 \pm 0.48^{d}$ & $1.42 \pm 0.05^{c}$ & $12.70 \pm 0.28^{c}$ & $38.24 \pm 0.13^{d}$ & $20.39 \pm 0.04^{\mathrm{a}}$ & $0.98 \pm 0.01^{b}$ & $0.67 \pm 0.01^{b}$ & 1.59 \\
\hline
\end{tabular}

Each value in the table represents the mean of three replicates. Means within each row bearing different superscripts are significantly $(P<0.05)$ different; C12:0, Lauric acid; C14:0, Myristic acid; C16:0, Palmitic acid; C16:1, Palmitoleic acid; C18:0, Stearic acid; C18:1, Oleic acid; C18:2, Linoleic acid, C18:3, Linolenic acid; C20:0, Arachidic acid; ${ }^{1,2}$ Yanty et al. (2012) and Yanty et al. (2011b); ${ }^{3}$ Yanty et al.(2011a). 
Table 2

Triaclyglycerol (TAG) composition of plant-based fats and lard

\begin{tabular}{|c|c|c|c|c|c|}
\hline & Avocado butter $^{1,2}$ & Cocoa butter & Palm oil & Mee fat & Lard $^{3}$ \\
\hline LLLn & $1.87 \pm 0.00^{a}$ & - & - & - & $1.54 \pm 0.21^{a}$ \\
\hline LLL & $0.85 \pm 0.07^{\mathrm{a}}$ & - & - & - & $0.68 \pm 0.21^{a}$ \\
\hline OLL & $3.23 \pm 0.02^{b}$ & - & - & $0.88 \pm 0.02^{c}$ & $4.68 \pm 0.08^{a}$ \\
\hline MMM & - & - & $0.21 \pm 0.01^{a}$ & - & - \\
\hline PLL & $4.21 \pm 0.00^{b}$ & $0.27 \pm 0.00^{e}$ & $2.08 \pm 0.03^{c}$ & $0.83 \pm 0.02^{d}$ & $7.05 \pm 0.06^{a}$ \\
\hline MPL & - & - & $0.54 \pm 0.01^{a}$ & - & - \\
\hline OOL & $9.00 \pm 0.03 a$ & - & $1.62 \pm 0.02^{d}$ & $5.00 \pm 0.14^{c}$ & $6.93 \pm 0.04^{b}$ \\
\hline POL & $19.29 \pm 0.06^{b}$ & $0.85 \pm 0.01^{e}$ & $9.96 \pm 0.01^{c}$ & $6.72 \pm 0.00^{d}$ & $20.00 \pm 0.27^{a}$ \\
\hline PPL & $4.03 \pm 0.06^{b}$ & $1.55 \pm 0.00^{\mathrm{e}}$ & $10.19 \pm 0.01^{\mathrm{a}}$ & $2.08 \pm 0.01^{d}$ & $2.62 \pm 0.04^{c}$ \\
\hline O०० & $11.42 \pm 0.01^{a}$ & $0.69 \pm 0.01^{c}$ & $3.97 \pm 0.02^{b}$ & $11.06 \pm 0.01^{a}$ & $4.33 \pm 0.21^{b}$ \\
\hline POO & $22.76 \pm 0.02^{\mathrm{c}}$ & $2.27 \pm 0.02^{e}$ & $24.76 \pm 0.01^{b}$ & $25.64 \pm 0.04^{a}$ & $20.67 \pm 0.11^{d}$ \\
\hline PPO & $12.43 \pm 0.00^{\circ}$ & $18.08 \pm 0.01^{\mathrm{b}}$ & $31.61 \pm 0.01^{\mathrm{a}}$ & $10.39 \pm 0.01^{\mathrm{e}}$ & $10.63 \pm 0.01^{d}$ \\
\hline PPP & $2.88 \pm 0.01^{b}$ & $0.26 \pm 0.01^{d}$ & $4.77 \pm 0.03^{a}$ & $0.33 \pm 0.01^{c}$ & $0.38 \pm 0.00^{c}$ \\
\hline StOO & $0.52 \pm 0.01^{\mathrm{e}}$ & $2.98 \pm 0.00^{c}$ & $2.72 \pm 0.02^{d}$ & $12.05 \pm 0.04^{a}$ & $3.62 \pm 0.04^{b}$ \\
\hline StPO & $0.57 \pm 0.02^{\mathrm{e}}$ & $40.78 \pm 0.1^{a}$ & $5.65 \pm 0.01^{d}$ & $14.86 \pm 0.01^{b}$ & $12.52 \pm 0.12^{c}$ \\
\hline PPSt & $0.11 \pm 0.01^{e}$ & $0.41 \pm 0.01^{c}$ & $0.92 \pm 0.01^{a}$ & $0.33 \pm 0.01^{d}$ & $0.81 \pm 0.00^{b}$ \\
\hline StOSt & - & $29.35 \pm 0.01^{a}$ & $0.52 \pm 0.01^{c}$ & $6.36 \pm 0.21^{b}$ & $0.83 \pm 0.01^{c}$ \\
\hline StStSt & - & $0.40 \pm 0.05^{b}$ & - & $0.23 \pm 0.01^{c}$ & $1.31 \pm 0.01^{a}$ \\
\hline Others & $6.83 \pm 0.04$ & $2.11 \pm 0.14$ & $0.48 \pm 0.01$ & $3.24 \pm 0.03$ & $1.41 \pm 0.33$ \\
\hline UUU & 26.37 & 0.69 & 12.68 & 16.94 & 18.16 \\
\hline UUS & 46.78 & 6.37 & 40.06 & 45.24 & 51.34 \\
\hline USS & 17.03 & 89.76 & 47.97 & 33.69 & 26.60 \\
\hline SSS & 2.99 & 0.66 & 5.90 & 0.89 & 2.50 \\
\hline
\end{tabular}

Each value in the table represents the mean of three replicates. Means within each row bearing different superscripts are significantly $(P<0.05)$ different; O: oleic; P: palmitic; L: linoleic; Ln: linolenic; St: stearic; U: unsaturated; S: saturated;

${ }^{1,2}$ Yanty et al. (2012) and Yanty et al.(2011b); ${ }^{3}$ Yanty et al. (2011a).

$(45.24 \%)$ and USS $(33.69 \%)$ as the dominant TAG molecular groups. In palm oil, USS (47.97\%) and UUS $(40.06 \%)$ are the most dominant TAG molecular groups, with PPO and POO as the predominant TAG molecules. In the case of cocoa butter, StPO and StOSt are the predominant TAG molecular species, and found to have excessive amount of USS TAG molecular group (89.76\%), but a very small amount of UUS TAG molecules (6.37\%). Hence, its TAG composition is very different from that of lard.

\subsection{Thermal characteristics}

\section{DSC cooling characteristics}

DSC cooling curves of plant-based fats are compared with that of lard as shown in Figure 1. While the cooling profile of lard is represented by curve (E), those of avocado butter, cocoa butter, palm oil and mee fat are represented by the curves (A), (B), (C) and (D), respectively. The onset of crystallization ( $T_{\text {onset }}$ ) of lard is $18.25^{\circ} \mathrm{C}$ while those of avocado butter, cocoa butter, palm oil and mee fat are $23.93^{\circ} \mathrm{C}, 17.01^{\circ} \mathrm{C}, 18.90^{\circ} \mathrm{C}$, and $26.86^{\circ} \mathrm{C}$, respectively. This shows that only palm oil $\left(18.90^{\circ} \mathrm{C}\right)$ among the plant-based fats is found to have an onset of crystallization value somewhat closer to that of $\operatorname{lard}\left(18.25^{\circ} \mathrm{C}\right)$. The cooling profile of lard used in this study is comparably similar to those reported previously (Marikkar et al., 2001; Yanty et al., 2011a). It is found to display exothermic transitions at two widely different temperature regions: two major transitions at $-18.7^{\circ} \mathrm{C}\left(\mathrm{e}_{3}\right)$ and $10.3^{\circ} \mathrm{C}\left(\mathrm{e}_{2}\right)$ with a shoulder peak at $16.8^{\circ} \mathrm{C}\left(\mathrm{e}_{1}\right)$.Similar to lard, plant-based fats, namely avocado butter, palm oil and mee fat are also found to display thermal transitions in both high and low temperature regions of their respective cooling curves. In contrast, the cooling curve displayed by cocoa butter is found to be different from the others as it has a single exothermic thermal transition at $13.40^{\circ} \mathrm{C}$. The co-crystallization of TAG molecular 


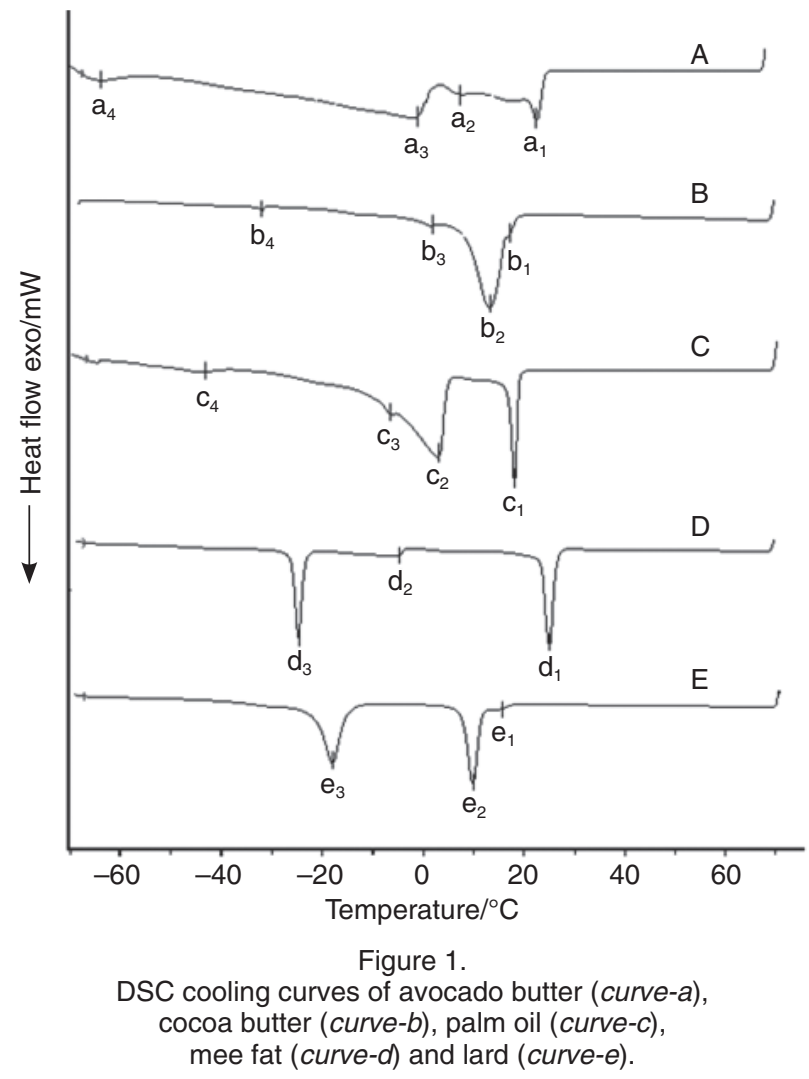

species within a narrow temperature region would have caused cocoa butter to display a single thermal transition.

\section{DSC melting characteristics}

DSC melting curves of plant-based fats are compared with that of lard as shown in Figure 2. While the melting profile of lard is represented by curve (E), those of avocado butter, cocoa butter, palm oil and mee fat are represented by curve $(A),(B),(C)$ and (D), respectively. The end-set of melting $\left(T_{\text {endset }}\right)$ of lard is $35.70^{\circ} \mathrm{C}$ while those of avocado butter, cocoa butter, palm oil and mee fat are $44.74^{\circ} \mathrm{C}, 29.48^{\circ} \mathrm{C}, 39.28^{\circ} \mathrm{C}$ and $38.86^{\circ} \mathrm{C}$, respectively. Among the plant-based fats, only mee fat is found to display $\mathrm{T}_{\text {endset }}$ value $\left(38.86^{\circ} \mathrm{C}\right)$ somewhat closer to that of lard $\left(35.70^{\circ} \mathrm{C}\right)$. Similar to the cooling profile, the melting profile of lard is also found to have thermal transitions in both low and high temperature regions. While the major peaks at $-3.59^{\circ} \mathrm{C}\left(\mathrm{e}_{2}\right)$ and a minor peak at $-21.4^{\circ} \mathrm{C}\left(\mathrm{e}_{1}\right)$ belong to a low-melting region $\left(<10^{\circ} \mathrm{C}\right)$, the cluster of peaks with transitions at $29.01^{\circ} \mathrm{C}\left(\mathrm{e}_{4}\right), 26.79^{\circ} \mathrm{C}\left(\mathrm{e}_{3}\right)$ and $32.46{ }^{\circ} \mathrm{C}\left(\mathrm{e}_{5}\right)$ can be designated as belonging to a high-melting region $\left(>10^{\circ} \mathrm{C}\right)$. The plant-based fats, namely avocado butter, palm oil and mee fat are also found to have high and low-melting transitions (Figure 2). For instance, the melting profile of mee fat is found to display a major peak $\left(d_{1}\right)$ at $-5.75^{\circ} \mathrm{C}$ with a shoulder peak $\left(\mathrm{d}_{2}\right)$ at $1.88^{\circ} \mathrm{C}$ in the low temperature region while a minor peak

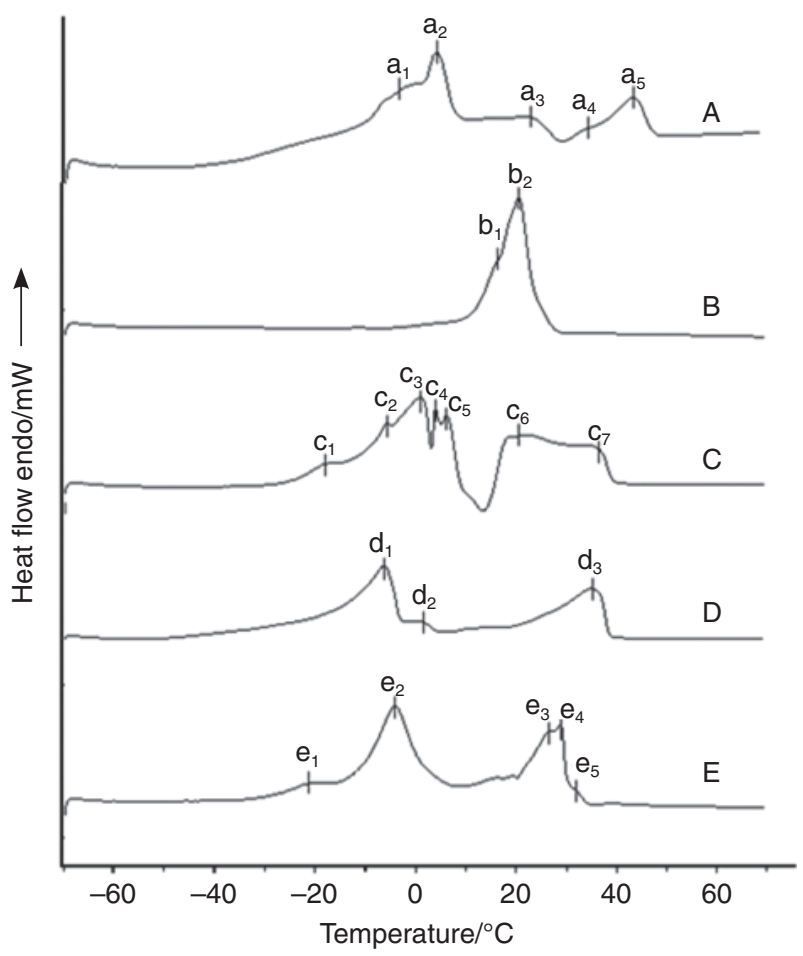

Figure 2.

DSC heating curves of avocado butter (curve-a), cocoa butter (curve-b), palm oil (curve-c), mee fat (curve- $d)$ and lard (curve-e).

$\left(d_{3}\right)$ appearing at $35.59^{\circ} \mathrm{C}$ could be designated as in the high temperature region. In contrast to lard and other plant-based fats, cocoa butter is found to display a single melting transition, which exists in the high temperature region (above $10^{\circ} \mathrm{C}$ ). As pointed out earlier, this could be due to the co-melting of cocoa butter TAG species within a narrow temperature range.

\subsection{Solidification behavior}

The solid fat content (SFC) profiles of plantbased fats and lard are compared as shown in Figure 3. The SFC of lard at $0^{\circ} \mathrm{C}$ was $30.8 \%$, while those of the plant-based fats namely cocoa butter, palm oil, mee fat and avocado butter are $93.99 \%, 68.63 \%, 33.1 \%$ and $18.02 \%$, respectively. Throughout the temperature region, the SFC values of avocado butter have always been lower than those of lard (Figure 3). Between the temperature range of $0^{\circ} \mathrm{C}$ to $20^{\circ} \mathrm{C}$, both palm oil and cocoa butter are found to have an SFC higher than that of lard. In this temperature range, mee fat is found to display an SFC profile closely similar to that of lard. However, the SFC profile of palm oil is found to become similar to that of lard in the temperature range of $25-40^{\circ} \mathrm{C}$. Interestingly, the SFC values of palm oil, mee fat and lard were closely similar to each other at $25^{\circ} \mathrm{C}$. The changing nature in the SFC profiles of plant-based fats and lard could be attributed to their differences in TAG molecular distributional patterns (Table 2). 


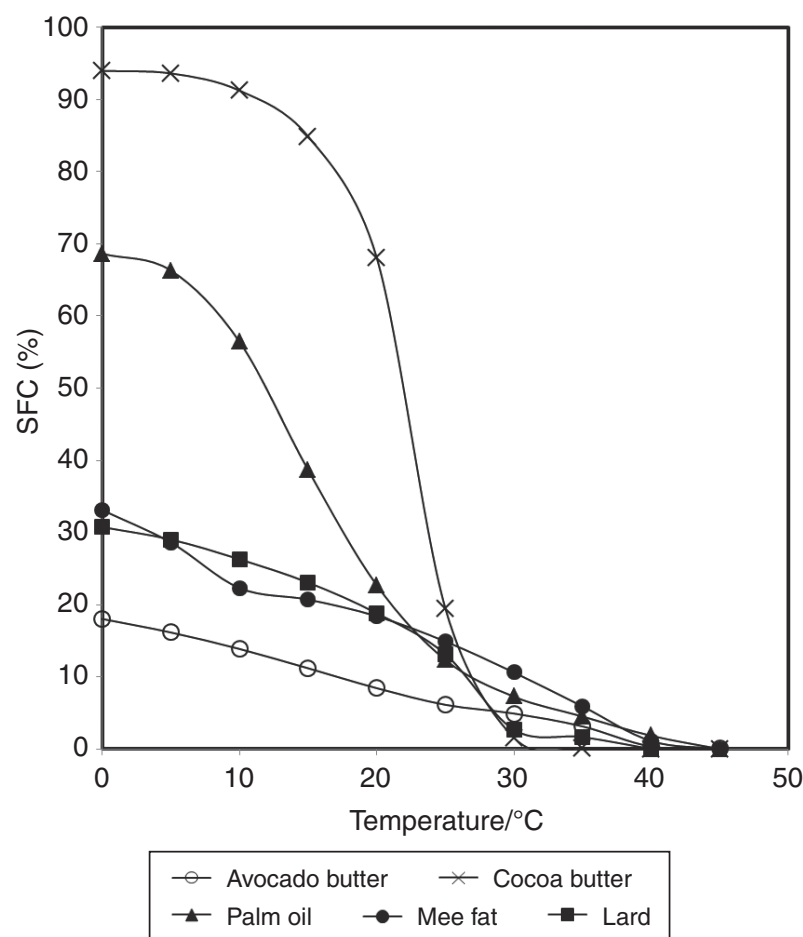

Figure 3.

Solid fat content profiles of selected plant-based fats and lard.

The apparent similarities in the SFC values of lard and mee fat in the range of $0-25^{\circ} \mathrm{C}$ could be due to some similarities between them with regard to the distribution of TAG molecular species. According to Table 2, both mee fat and lard are found to possess a clear descending order with respect to the proportional distribution of UUS, USS, UUU, and SSS groups of TAG molecular species (i.e UUS $>$ USS $>$ UUU $>$ SSS). Although avocado butter and lard are found to possess $\mathrm{POO}$ and $\mathrm{POL}$ as their predominant TAG molecules, the proportion of triunsaturated (UUU) TAG molecules in avocado butter $(26.37 \%)$ (Table 2 ) is much higher than that of lard $(18.16 \%)$. On the other hand, in a greater part of the temperature region, cocoa butter and palm oil are found to possess higher SFC values in comparison to the corresponding SFC values of lard. Cocoa butter $(89.76 \%)$ and palm oil (47.97\%) are found to possess enhanced proportions of USS TAG molecules in comparison to lard (Table 2). In addition, the proportions of UUS $(6.37 \%)$ and UUU $(0.69 \%)$ of cocoa butter are extremely low. Based on the results presented in Fig. 3, blending of either palm oil or cocoa butter with avocado butter at an appropriate ratio would provide a lipid mixture which simulates the solidification behavior of lard.

\section{CONCLUSIONS}

Having thermal transitions at low $\left(<0^{\circ} \mathrm{C}\right)$ and high-temperature $\left(>0^{\circ} \mathrm{C}\right)$ regions is a common characteristic feature between lard and plantbased fats such as palm oil, avocado butter and mee fat. In the case of cocoa butter, this characteristic feature is not found since its TAG molecular species are found to co-crystallize or melt within a narrow temperature region. Among the plant-based fats studied, the SFC profile of mee fat is found to be compatible to that of lard, within a $0-25^{\circ} \mathrm{C}$ temperature range. Both lard and palm oil are found to have similar solidification behavior within the $25-40^{\circ} \mathrm{C}$ temperature range. This study concludes that a fat blend which simulates the SFC profile of lard may be prepared by blending either palm oil or cocoa butter with avocado butter in an appropriate ratio.

\section{ACKNOWLEDGEMENTS}

The authors gratefully acknowledge the financial support received under the Research University Grants Scheme (Grant No. 02-01-0889 RU) of the Universiti Putra Malaysia.

\section{REFERENCES}

AOAC. 2007. Official methods of analysis of AOAC International. 18th ed. Association of Official Analytical Chemists, Washington.

AOCS. 1999. Official methods and recommended practices of the American Oil Chemists' Society. 5th ed. American Oil Chemists' Society, Champaign.

Marikkar JMN, Ghazali HM, Long K, Lai OM. 2003. Lard uptake and its detection in selected food products deep-fried in lard. Food Res. Intel. 36, 1047-1060.

Marikkar JMN, Ghazali HM, Long K. 2010. Composition and thermal characteristics of Madhuca longifolia seed fat and its solid and liquid fractions. J. Oleo Sci. 59, 7-14.

Marikkar JMN, Lai OM, Ghazali HM, Che Man YB, Peiris TSG, Lai OM. 2005. Distinguishing lard from other animal fats in admixtures of some vegetable oils using liquid chromatographic data coupled with multivariate data analysis. Food Chem. 91, 5-14.

Marikkar JMN, Lai OM, Ghazali HM, Che Man YB. 2001. Detection of lard and randomised lard as adulterants in RBD palm oil by differential scanning calorimetry. J. Am. Oil Chem. Soc. 78, 1113-1119.

Nurjuliana M, Che Man YB, Mat Hashim D. 2010. Analysis of lard's aroma by an electric nose for rapid halal authentication. J. Am. Oil Chem. Soc. 88, 7582.

Ospina-E JC, Cruz-S A, Perez Alvarez JA, FernándezLópez J. 2011. Development of combinations of chemically modified vegetable oils as porkbackfat substitutes in sausages formulation. Meat Sci.84, 491-497.

PORIM. 1995. PORIM test methods. Palm Oil Research Institute of Malaysia, Kuala Lumpur.

Rashood KA, Shaaban RRA, Moety EMA, Rauf A. 1996. Compositional and thermal characterization of genuine and randomized lard: a comparative study. J. Am. Oil Chem. Soc. 73, 303-309. 
Riaz MN, Chaudry MM. 2004. Halal Food Production. CRC Press, Florida.

Segall SD, Artz WE, Raslan DS, Ferraz VP, Takahashi JA. 2005. Analysis of triacylglycerol isomers in Malaysian cocoa butter using HPLC-mass spectroscopy. Food Res. Intel. 38, 167-174.

Wikipedia. 2012. Lard. en.wikipedia.org/lard. Accessed on Jan 2012.

Yanty NAM, Marikkar JMN, Che Man YB, Long K. 2011 a. Composition and thermal analysis of lard stearin and lard olein. J. Oleo Sci. 60, 333-338.
Yanty NAM, Marikkar JMN, Long K. 2011b. Effect of varietal differences on composition and thermal characteristics of avocado oil. J. Am. Oil Chem. Soc. 88, 1997-2003.

Yanty NAM, Marikkar JMN, Che Man YB. 2012. Effect of fractional crystallization on composition and thermal characteristics of avocado (Persea americana) butter. $J$ Therm Anal Calorim. (In press, DOI 10. 1007/ s10973-011-2055-y).

Recibido: 22/2/12 Aceptado: 16/4/12 